Yayın Geliş Tarihi: 07.04.2015

Yayına Kabul Tarihi: 14.07.2015

Online Yayın Tarihi: 24.12.2015

DOI: 10.18613/deudfd.78984
Dokuz Eylül Üniversitesi

Denizcilik Fakültesi Dergisi

Cilt:7 Sayı:2 Yıl:2015 Sayfa:154-170

ISSN:1309-4246

\title{
AN ANALYSIS OF THE EFFECTS OF MAJOR OIL COMPANIES ON CREW SELECTION CRITERIA FOR TANKER OPERATING SHIP MANAGEMENT COMPANIES*
}

\author{
Remzi FIŞKIN ${ }^{1}$ \\ Yusuf ZORBA ${ }^{2}$
}

\begin{abstract}
Tanker shipping which is a special sub-sector of maritime transportation industry plays an important role for the world trade. As oil and its derivatives transported by tankers is the fundamental component for developing industries, its transportation becomes an indispensable issue. Though petroleum and chemical transportation is important for all industries, due to its structural properties, these cargoes include major risks for the environment. There have been some enforcement and impositions to the tanker operating ship management companies to minimize these risks. Herein, MOC (Major Oil Companies), the most important players in the world petroleum industry, has made such impositions on tanker operating ship management companies. Enforcement and impositions on human factor which is the most significant element in a business has a critical importance to minimize these risks. Thus, this study aims to reveal the effects of MOC on the personnel selection criteria of the ship management companies that operate tankers. To achieve this aim, a total of 12 companies operating in Turkey and having largest fleet were selected. An interview was conducted through these companies and the data obtained were analyzed by content analysis of qualitative research methods. As a result, it is revealed that major oil companies have an impact on personnel selection process
\end{abstract}

This article was prepared from the Master Thesis titled "Önde Gelen Petrol Şirketlerinin Tanker İşleten Gemi Yönetim Firmalarının Personel Seçim Ölçütlerine Etkilerinin Analizi”, Dokuz Eylül University, Graduate School of Social Sciences, Department of Marine Transportation Engineering, İzmir, 2013.

${ }^{1}$ Res. Asst., Dokuz Eylül University, Maritime Faculty, Izmir, Ordu University, Fatsa Faculty of Marine Sciences, Ordu, remzi.fiskin@ deu.edu.tr

2 Assoc. Prof. Dr., Dokuz Eylül University, Maritime Faculty, Izmir, yusuf.zorba@deu.edu.tr 
and activities. Generally, these effects have been about duration of the contract, the number of crew required to be on board, company internal promotion procedures, recruitment process of new employees to the company, and crew training.

Keywords: Tanker management, human resources, $M O C$, crew selection, oil and chemical transportation.

\title{
ÖNDE GELEN PETROL ŞİRKETLERININ TANKER İŞLETEN GEMI YÖNETIM FIRMALARININ PERSONEL SEÇIM ÖLÇÜTLERINE ETKILERININ ANALIZİ
}

\begin{abstract}
$\ddot{O Z E T}$
Özel bir taşımacılık modu olan denizyolu taşımacılığının alt sektörü olan tanker taşımacılı̆̆ı dünya ticareti için büyük önem taşımaktadır. Tankerler aracıllğ ile taşınan petrol ve türevlerinin gelişen endüstrilerde önemli bir enerji kaynă̆ olduğu düşünüldü̆ğünde nakliyesi de vazgeçilmez hale gelir. Petrol ve kimyasal taşımacılığı endüstriler için önemli olmakla birlikte, bu taşınan yükler yapıları ve özellikleri gereği çevre açısından büyük riskler taşımaktadır. Bu riskleri en aza indirmede tanker taşımacıllı̆̆ yapan firmalar üzerinde bazı yaptırım ve dayatmalar mevcuttur. Bu noktada, dünya petrol endüstrisine yön veren aktörler içinde en önemlisi olan önde gelen petrol şirketleri (MOC - Major Oil Companies) tanker işletmesi yapan firmalar üzerinde bu dayatmaları yüksek oranda hissettirmektedir. Bir işletmenin en önemli unsuru olan insan faktörü üzerinde yapılacak olan yaptırım ve dayatmalar bu risklerin meydana gelme olasılığını en aza indirmede hayati önem taşımaktadır. Buradan hareketle, bu çalışma tanker işleten gemi yönetim firmalarının personel seçim ölçütlerinin belirlenmesinde MOC'ların etkilerinin neler olduğunu ortaya çıkarmayı amaçlamaktadır. Bu amacı gerçekleştirmek için Türkiye'de tanker işletmesi yapan ve en geniş filoya sahip 12 firma yöneticileri ile görüşmeler yapılmış ve elde edilen veriler nitel araştırma tekniklerinden olan içerik analizi yöntemiyle incelenmiştir. Araştırmada sonuç olarak, önde gelen petrol şirketlerinin kiracısı oldukları tanker işletmeciliği yapan firmaların personel seçim süreçlerinde ve faaliyetlerinde etki ve yaptırımlarının olduğu ortaya çıkmıştır. Bu etki ve yaptırımların genellikle; kontrat süreleri, gemide bulunmast gereken gemi adamı sayısı, şirket içi terfi prosedürleri, yeni personelin firmaya dâhil edilmesi süreçleri ve personel ĕgitimi konularında yoğunlaştı̆̆ sonucuna varılmıştır.
\end{abstract}

Anahtar Kelimeler: Tanker işletmeciliği, insan kaynakları, MOC, gemi adamı seçimi, petrol ve kimyasal taşımacılığı. 


\section{INTRODUCTION}

In general, transportation consists of five sub-system including air, land, sea, rail and pipeline. However, a large portion of the goods subject to world trade is transported by sea transportation (ITO, 2004; 5). Ability to move large party goods at one time is major cause for taking a greater share of world trade for sea transport compared to other transport systems.

Maritime transportation is also one of the three preferred methods for transporting large quantities of oil (Rowbotham, 2014: 78). High amounts of petroleum and derivatives are transported from place to place by tankers built in large size. These cargoes transported by tanker include great risks due to their properties. Any potential harm to the environment of an accident that may occur and the amount of compensation paid by the company is very large dimensions. This brings along some standards. Oil companies which is expressed as a giant on the world and called major oil companies (MOC) are dictates these standards to tanker companies carrying their cargoes (Alemdağ, 2008: 25). Major oil companies were previously called "Seven Sister" that operates in every area of oil industry. In 1950s, these seven companies (Anglo-Persian Oil Company (later it became BP), Gulf Oil (bought by Chevron), Royal Dutch Shell, Chevron, Total, Exxon (then it merged with Mobil), Texaco (bought by Chevron)) provided more than $90 \%$ world oil productions (Özev, 2010: 78).

Manpower supply which is extremely important for a company is the process of selecting the most proper candidate (Bingöl, 2010: 233). The process is carried out by determining quality and quantity of company's requirement (Karatepe, 2012: 27) and evaluating the skills, interests and educational status (Sözen, 1973: 8) of the proper candidate within a particular group (Geylan, 1992: 100). Selecting the right human resources provides high motivation to the company (Kenan, 1996: 60) and it will also be a right investment that gives power and faster development to a team (Andersen, 2000: 1).

Factors affecting the human resources selection process are listed as followed: laws (Mondy et al. 2002: 177), selection process (Bingöl, 2010: 233), organizational structure and hierarchy, size of enterprise (Acar ve 
Kaynak, 2002: 124), supply and demand equilibrium, candidate pool and profile (Bingöl, 2010: 236), and wage policy (Özdoğan, 2005: 65).

The impositions and enforcements that have been imposed on the human factor which is the most important aspects for a company are critical for minimizing the probability of occurrence of such risks. Human factor also plays a key role to achieve high levels of productivity and provide high quality services to shipping companies (Hinrichs et al., 2013). Thus, this study aims to find out the effects of major oil companies on crew selection criteria for tanker operating ship management companies. To accomplish the goal, interviews have conducted to a total of 12 companies that engage in tanker operations. The data obtained from these companies were analyzed by content analysis of qualitative research methods.

Within the scope of the study, the paper is organized into five main sections. The first section introduces general information about MOC and factors affecting the human resources selection process. Section 2 finds out the studies in the literature that related to our study and expresses motivation behind the research. Section 3 gives information as to methodology performed in the study. Section 4 is the findings and discussion section. Final section provides results and recommendations for further research.

\section{LITERATURE REVIEW}

A few studies related to crew selection criteria for ship management companies were encountered. One of them is about crew selection criteria for ship owning company that operate in İzmir region (Hanhan, 2006). A crew selection criterion of companies operating in İzmir region was aimed to determine via interview technique used research question. As a result of research, some of the criteria such as experience, reference, foreign language proficiency, are crucial to select employee. The other study prepared by Blanc (2003) is about naval officer selection in Canada. In the study, two studies evaluating the Maritime Officer Selection Test (MOST) were conducted. Study 1 examined the psychometric properties of the individual. Study 2 claimed to determine the selection of future naval officers. As a result of the study, the MOST does not measure what it was intended to assess (i.e. memory, decision making, selective attention), yet it does evaluate other ability required for naval officer training performance (i.e. 
general reasoning and spatial scanning). Another study prepared by Arslan (2006) is also about human resources management for Turkish Seafarers. In this study, information about the selection criteria for seafarers was shared and analyzed.

On the other hand, it is possible to be reached lots of study about personnel selection in the literature. Some of them are as follows: İbicioğlu and Ünal (2014) conducted a study about human resource manager selection by analytic hierarchy process. They developed a model on the base of analytic hierarchy process and applied the model for the selection of human resource manager among candidates. İstemi (2006) examined Analytical Hierarchy Process (AHP) Method which can be applied in the personnel selection. During the method inspector assistants were selected by using AHP Method. The relationship between personnel selection and performance of selected personnel was investigated. Harbili (2009) aimed to reveal the importance of the employment process and to provide suggestions about selection process in order to establish the most appropriate human resources management system. Erdoğdu (2013) emphasized personnel selection criteria, provided information regarding psycho-technical tests and applied the test to a private enterprise to elaborate the importance of the test during the personnel selection process. Djabatey (2012) intended to assess the effectiveness of the recruitment and selection practices of a company.

The motivation of the study aims to reveal that what kind of impacts and sanctions MOC enforce to tanker operating ship management companies. When examining the literature, the absence of any studies revealing such impacts and sanctions increases the importance and motivation of this study. In this respect, the study is expected to contribution to literature. The study also aimed to reveal the challenges associated with the recruitment and selection practices and to give advice to improve human resource planning and development. Besides aforementioned study, the books and reports (Gusdorf, 2009; Maloney, 2001; Ashby and Pell, 2002; Hall, 2012) about how to select and recruit proper people are possible to be accessed from literature, as well. 


\section{METHODOLOGY}

The study is a qualitative research approach. Qualitative research is one of the approaches that researches use when they want to expose information and analyze data about the nature of reality or the world (Mtsweni, 2008:55). According to Mason (1997:4), the qualitative research is also concerned with how the social world is interpreted, understood or produced (as cited by Mtsweni, 2008:56). Maykut and Morehouse (1994:45) also stated that the qualitative approaches are practical while the researcher aims to have an understanding of a human phenomenon as well as to find out the meaning given to events that subjects experience (as cited by Mtsweni, 2008:8).

In this study, the face to face interview technique was used for data collection for a predetermined purpose. As shown in table 2, a total of 12 tanker management companies which have the largest fleet that operating in Turkey have been included in the study.

The interview technique is one of the most commonly used techniques in social science research. The interview allowed researchers to explore all questions in all cases (Theotokas and Progoulaki, 2007). According to Karasar (2005:165), interview is a data collecting technique through verbal communication. Another description is generated by Stewart and Cash (1985:3), interview is a reciprocal and interactive communication process based on asking questions and answers. Stewart and Cash (1985:3) also specify that the concept offers an interpersonal connection between the interviewer and participants. According to Chirban (as cited by Mtsweni, 2008:11) "an interview, in the true sense of the word, gives the "inner view" of the interviewed person.

For analysis of sentences obtained from the participants "weight score (intensity)" method was used as a type of content analysis. The method was also used and implemented in some research studies (Nas, 2006; Sakar, 2013). In this method each research questions was coded. During coding, the expressions given by each participant have attempted to follow certain patterns. According to the level of expression, the weight score are given to certain patterns. The purpose of doing this is to make distinction between the ordinary expressions and expression that especially to be emphasized. Additionally, the weight score of the concepts can be also determined by 
weight defined to expression code. For these reasons, weight score (intensity) has been decided to use during to digitization of data (Neuman as cited by Nas, 2006: 2008).

Table 1: Weight Score of Analysis Codes

\begin{tabular}{|c|c|c|}
\hline $\begin{array}{c}\text { Type of Expression } \\
\text { Code }\end{array}$ & Sample & $\begin{array}{c}\text { Weight } \\
\text { Score }\end{array}$ \\
\hline Normal Expression & $\begin{array}{c}\text { Criteria that Acting decision- } \\
\text { making in supplying employee; } \\
\text { experience,...,... can be listed. }\end{array}$ & 1 \\
\hline Important Expression & $\begin{array}{c}\text { Experience is important to us in } \\
\text { personnel selection }\end{array}$ & 2 \\
\hline Very Strong & $\begin{array}{c}\text { Experience is one of the most } \\
\text { important criteria in personnel } \\
\text { Expression }\end{array}$ & \begin{tabular}{c} 
selection. \\
\hline
\end{tabular}
\end{tabular}

Source: Adapted by Nas, 2006: 207.

The profile information of the companies included in the research is located in Table 2.

Table 2: Companies Included in the Scope of Research

\begin{tabular}{|c|c|c|c|c|}
\hline Company & $\begin{array}{c}\text { Founding } \\
\text { Year }\end{array}$ & $\begin{array}{c}\text { Number of } \\
\text { Tanker } \\
\text { Ships }\end{array}$ & $\begin{array}{c}\text { Total } \\
\text { Capacities of } \\
\text { the Ships } \\
\text { (x1000Dwt) }\end{array}$ & $\begin{array}{l}\text { Type of the } \\
\text { Ships }\end{array}$ \\
\hline 1 & 2002 & 10 & 50,5 & Chemical \\
\hline 2 & 1984 & 8 & 113,5 & $\begin{array}{c}\text { Chemical, } \\
\text { Product }\end{array}$ \\
\hline 3 & 1960 & 13 & 403 & $\begin{array}{c}\text { Chemical, } \\
\text { Crude oil, } \\
\text { Product, LPG }\end{array}$ \\
\hline 4 & 1994 & 10 & 160 & $\begin{array}{c}\text { Chemical, } \\
\text { Crude oil, } \\
\text { Product }\end{array}$ \\
\hline 5 & 2006 & 26 & 250 & Chemical \\
\hline 6 & 1974 & 5 & 244 & $\begin{array}{c}\text { Chemical, } \\
\text { Crude oil, } \\
\text { Product }\end{array}$ \\
\hline
\end{tabular}


Table 2: Companies Included in the Scope of Research (Cont.)

\begin{tabular}{|c|c|c|c|c|}
\hline Company & $\begin{array}{c}\text { Founding } \\
\text { Year }\end{array}$ & $\begin{array}{c}\text { Number of } \\
\text { Tanker } \\
\text { Ships }\end{array}$ & $\begin{array}{c}\text { Total } \\
\text { Capacities of } \\
\text { the Ships } \\
\text { (x1000Dwt) }\end{array}$ & $\begin{array}{c}\text { Type of the } \\
\text { Ships }\end{array}$ \\
\hline $\mathbf{7}$ & 1990 & 4 & 603 & Crude oil \\
\hline $\mathbf{8}$ & 1940 & 8 & 122,5 & $\begin{array}{c}\text { Chemical, } \\
\text { Crude oil, } \\
\text { Product }\end{array}$ \\
\hline $\mathbf{9}$ & 1980 & 10 & 70 & $\begin{array}{c}\text { Chemical, } \\
\text { Product, LPG }\end{array}$ \\
\hline $\mathbf{1 0}$ & 2005 & 5 & 70 & $\begin{array}{c}\text { Chemical, } \\
\text { Product }\end{array}$ \\
\hline $\mathbf{1 1}$ & 1999 & 12 & 1300 & $\begin{array}{c}\text { Chemical, } \\
\text { Crude oil, } \\
\text { Product, }\end{array}$ \\
\hline 12 & 1975 & 32 & 545 & $\begin{array}{c}\text { Crude oil, } \\
\text { Product }\end{array}$ \\
\hline
\end{tabular}

\section{FINDINGS}

The weight scores determined as a result of the response to the question of what the human resources selection criteria and application of tanker operating companies are shown in Table 3. As seen in the table, the most important criteria is "tanker ship experience" with the weight score of 22 which was remarked by 8 companies. "Foreign Language" and "Reference" stands out as the other important criteria with the score of 15 which was remarked by 9 companies.

Table 3: "Analysis of the Human Resource Selection Criteria of Company" Summary of the Analysis

\begin{tabular}{|c|c|c|}
\hline Concepts & $\begin{array}{c}\text { Weight } \\
\text { Score }\end{array}$ & $\begin{array}{c}\text { Number of Companies } \\
\text { Using the Expression }\end{array}$ \\
\hline Tanker Ship Experience & 22 & 8 \\
\hline Foreign Language & 15 & 9 \\
\hline Reference & 15 & 9 \\
\hline
\end{tabular}


Table 4 also shows the effects of MOC on crew selection criteria. Weight score is 21 , as shown in the table, stated that MOC had a direct effect on the determination and implementation of human resource selection criteria according to personnel managers of 7 companies. "Experience of Inspection" and "Compliance to Matrix*" are other important criteria that are taken into consideration with the score of 7 which was remarked by 3 companies.

Table 4: "Analysis of the MOC's Expectations and Effects on Determination of Crew Selection Criteria and Providing Employment of Crew to the

Company" Summary of the Analysis

\begin{tabular}{|c|c|c|}
\hline Concepts & Weight Score & $\begin{array}{c}\text { Number of Companies } \\
\text { Using the Expression }\end{array}$ \\
\hline $\begin{array}{c}\text { Being under the Direct Effect from } \\
\text { MOC }\end{array}$ & 21 & 7 \\
\hline Experience of Inspection & 7 & 3 \\
\hline Compliance to Matrix & 7 & 3 \\
\hline
\end{tabular}

The data related to whether or not the effects of MOC on crew contract duration and number of personnel required being on board is shown in Table 5. Weight score is 22 , as shown in the table, stated that there was no effect of MOC on contract duration according to company representatives of 8 companies. In terms of number of crew on board, on the other hand, they may request more personnel on occasion and also request more personnel depending on type of cargo.

Table 5: "Analysis of the Effects of MOC on Crew Contract Duration and Number of Personnel Required Being on Board" Summary of the Analysis

\begin{tabular}{|c|c|c|}
\hline Concepts & Weight Score & $\begin{array}{c}\text { Number of } \\
\text { Companies Using } \\
\text { the Expression }\end{array}$ \\
\hline $\begin{array}{c}\text { There is No Effect on Contract } \\
\text { Duration }\end{array}$ & 22 & 8 \\
\hline Request More Personnel on Occasion & 19 & 10 \\
\hline $\begin{array}{c}\text { Request More Personnel Depending on } \\
\text { Type of Cargo }\end{array}$ & 13 & 5 \\
\hline
\end{tabular}

\footnotetext{
* Matrix is the experience of officers with respect to rank, company and type of vessel. According to matrix target, every officer must have minimum experience in their rank, in their company and also type of vessel.
} 
Table 6 shows that whether the companies employ foreign personnel and the reason of the selection of foreign personnel. A total of 9 interviewed companies, weight score is 9 as shown in the table, remarked that they didn't run foreign personnel. Besides, a total of 2 companies gave the "Providing Ease Reach the Matrix Target" as a reason of the selection of foreign personnel. Conversely, 1 company stated that the "Current Turkish Personnel Provides Matrix Target".

Table 6:"Analysis of the Employment of Foreign Personnel and the Reason of the Selection of Them" Summary of the Analysis

\begin{tabular}{|c|c|c|}
\hline Concepts & $\begin{array}{c}\text { Weight } \\
\text { Score }\end{array}$ & $\begin{array}{c}\text { Number of } \\
\text { Companies Using } \\
\text { the Expression }\end{array}$ \\
\hline Does not Employ Foreign Personnel & 9 & 9 \\
\hline Providing Ease Reach the Matrix Target & 5 & 2 \\
\hline $\begin{array}{c}\text { Current Turkish Personnel Provides } \\
\text { Matrix Target }\end{array}$ & 3 & 1 \\
\hline
\end{tabular}

The data obtained for determining the personnel that will be gone a board, companies are subject to difficulties about compliance to matrix and how to solve these difficulties are shown in Table 7 . While a total of 8 interviewed companies, weight score is 20 as shown in the table, remarked that they were subject to difficulties in terms of matrix, a total 4 of them, weight score is 10 as shown in the table, remarked that they did not encounter any difficulties like that. Besides, a total of 5 company representatives stated that they run personnel reserved for voyage to solve these problems. 
Table 7: "Analysis of the Difficulties Compliance to Matrix and Implementation for Solution of These Problems" Summary of the Analysis

\begin{tabular}{|c|c|c|}
\hline Concepts & $\begin{array}{c}\text { Weight } \\
\text { Score }\end{array}$ & $\begin{array}{c}\text { Number of } \\
\text { Companies Using } \\
\text { the Expression }\end{array}$ \\
\hline $\begin{array}{c}\text { Being Subject to Difficulties in Terms } \\
\text { of Matrix }\end{array}$ & 20 & 8 \\
\hline Personnel Reserved for Voyage & 11 & 5 \\
\hline $\begin{array}{c}\text { Not Encounter Any Difficulties in } \\
\text { Terms of Matrix }\end{array}$ & 10 & 4 \\
\hline
\end{tabular}

Table 8 shows weight scores related to application to retain personnel who have worked at the company for a long time. A total of 11 interviewed companies, weight score is 20 as shown in the table, implemented "seniority" to hold the personnel. "Timely Submission of Salary" and "Having a Good Relationship and Communication within the Company" are other important implementation and factor for retain the personnel.

Table 8: "Analysis of the Implementation for Retain the Personnel Who Have Worked at the Company for a Long Time" Summary of the Analysis

\begin{tabular}{|c|c|c|}
\hline Concepts & $\begin{array}{c}\text { Weight } \\
\text { Score }\end{array}$ & $\begin{array}{c}\text { Number of } \\
\text { Companies Using } \\
\text { the Expression }\end{array}$ \\
\hline Seniority & 20 & 11 \\
\hline Timely Submission of Salary & 17 & 7 \\
\hline $\begin{array}{c}\text { Having a Good Relationship and } \\
\text { Communication within the Company }\end{array}$ & 7 & 3 \\
\hline
\end{tabular}

The data obtained for the implementations related to the personnel that have received a higher qualification in license is shown in Table 9. A total of 6 interviewed companies, weight score is 14 as shown in the table, remarked that the trusted personnel could be directly gone a broad if the matrix value gave a permission. "Positive Report from At Least 1 Captain" and "Working at Lower Qualification at Least 12 Months" are other prominent promotion procedures according to companies with the score of 14 and 12, respectively. 
Table 9: "Analysis of the Promotion Procedures Related to the Personnel That Have Received a Higher Qualification in License" Summary of the Analysis

\begin{tabular}{|c|c|c|}
\hline Concepts & $\begin{array}{c}\text { Weight } \\
\text { Score }\end{array}$ & $\begin{array}{c}\text { Number of } \\
\text { Companies Using } \\
\text { the Expression }\end{array}$ \\
\hline $\begin{array}{c}\text { The Trusted Personnel Could Be } \\
\text { Directly Gone a Broad if the Matrix } \\
\text { Value Gave a Permission }\end{array}$ & 14 & 6 \\
\hline Positive Report from at Least 1 Captain & 14 & 6 \\
\hline $\begin{array}{c}\text { Working at Lower Qualification at } \\
\text { Least 12 Months }\end{array}$ & 12 & 4 \\
\hline
\end{tabular}

The data obtained for whether companies are using TOTS (Tanker Officers Training Standards)* as a training standards and what kind of training that they are applying to the crew are show in Table 10. All of the interview companies, weight score is 24 as shown in the table, remarked that TOTS was not applied as a training standard. On the other hand, a total of 7 companies stated that the TOTS would be applied in soonest time and a total of 5 companies also stated that the training system similar to TOTS is available within organization.

Table 10: "Analysis of the TOTS Practices and the Training to Be Applied to Crew" Summary of the Analysis

\begin{tabular}{|c|c|c|}
\hline Concepts & $\begin{array}{c}\text { Weight } \\
\text { Score }\end{array}$ & $\begin{array}{c}\text { Number of } \\
\text { Companies Using } \\
\text { the Expression }\end{array}$ \\
\hline TOTS Not to Be Applied & 24 & 12 \\
\hline To Be Applied in Soonest Time & 14 & 7 \\
\hline $\begin{array}{c}\text { The Training System Similar to TOTS } \\
\text { is Available }\end{array}$ & 10 & 5 \\
\hline
\end{tabular}

${ }^{*}$ TOTS is intended to provide the tanker industry with a standard that ensures tanker officer competence through onboard and shore training, evaluating "time in rank" and "time with company" and also easing the problems and difficulties that tanker owners are encountering with the different "officer matrix" requirements of certain charterers. INTERTANKO, 2013. 
Table 11 shows the weight scores related to MOCs' demands on crew training and the impact of these demands while determining the company training standard. A total of 7 interviewed companies, weight score is 20 as shown in the table, remarked that they created the crew training standard which should include cargo handling and ship handling training at the request of MOC.

Table 11: "Analysis of the Effects of Expectations and Demands of MOC in Determining the Company Training Standard" Summary of the Analysis

\begin{tabular}{|c|c|c|}
\hline Concepts & $\begin{array}{c}\text { Weight } \\
\text { Score }\end{array}$ & $\begin{array}{c}\text { Number of } \\
\text { Companies Using } \\
\text { the Expression }\end{array}$ \\
\hline $\begin{array}{c}\text { In Accordance with Demand of } \\
\text { MOC }\end{array}$ & 20 & 7 \\
\hline Cargo handling & 8 & 8 \\
\hline Ship handling & 6 & 6 \\
\hline
\end{tabular}

\section{CONCLUSION}

Firstly, profile of the company within scope of the study was analyzed. In this context, a total of 143 tanker ship is under management of the companies subject to investigation. The total numbers of seafarers who work in these companies have been identified as 8595 together with off.

MOC; is one of the main actors of the oil and chemical industry which are developing enforcement and implementation on tanker management companies which transport their cargoes. In this respect, it is revealed that MOC have an impact on the process of personnel selection and human resources activities of tanker management companies. In this respect, the most of the interviewed companies create the crew training standards and the process of personnel selection and human resources activities at the request of MOC. In terms of contract duration there is no effect of MOC on. But, MOC have a direct effect on the determination and implementation of human resource selection criteria. "Tanker experience" identified as the most important criteria for the tanker operating ship management companies. Hence, it is understood that the employment of the personnel without tanker experience has low probability. "Vetting Inspection" performance values are 
also considered as a personnel selection criteria. Working hours in rank are taken in the account for new personnel to be employed. It shows that experience in rank is important for companies in terms of compliance to matrix. TOTS is not applied as a training standard by the whole companies that interviewed. "Seniority" is implemented by the companies to hold experienced crew within the organization. The most of the interviewed companies are subject to difficulties in terms of matrix and the most of the interviewed companies don't run foreign personnel. Besides all these, other effects of MOC are summarized as follows:

- Having an effect on the company promotion procedures.

- Having an effect on handover procedures.

- Having an effect on the number of personnel required to be on board.

- Requesting an extra officer and seaman according to type of operation, voyage zone and characteristic feature of cargo to be transported.

- Impact on the availability of personnel from different nationalities.

- Impact on company internal and external training.

Recommendations for further research are listed below:

- The scope of research can be expanded by including more number of tanker management companies.

- Officers and seamen may also be included in the study in addition to company managers.

- Foreign tanker management companies may be included in the sample.

- The results obtained using different research methods can be compared with the results of this study.

\section{REFERENCES}

Acar, A.C., \& Kaynak, T. (2002). Insan Kaynakları Temin ve Seçimi. İstanbul: Dönence Publication.

Alemdağ, Ö. (2008). An approach to meet tanker training requirements. In: Proceedings of International Maritime Lecturers Association $16^{\text {th }}$ Conference, 14-17 October, 2008, İzmir/Turkey, pp. 25-34. 
Andersen, A. (2000). Personnel recruitment and selection methods. Human Resource Journal, 9, 7-12.

Arslan, Ö. (2006). Türk gemi adamlart için insan kaynakları yönetimi, Degree of Master Thesis, Turkey: İstanbul Technical University, Graduate School of Science Engineering and Technology, İstanbul.

Ashby, F. C., \& Pell, A. R. (2002). Embracing excellence. Executive Book Summaries, 24 (4), 1-8.

Bingö1, D. (2010). Insan Kaynakları Yönetimi. İstanbul: Beta Publication.

Blanc, J.R. (2003). Naval officer selection in Canada: An evaluation of the maritime officer selection test, Degree of Master Thesis, Saint Mary's University, Canada.

Djabatey, E. N. (2012). Recruitment and selection practices of organizations, A case study of Hfc Bank (Gh) Ltd., Degree of Master Thesis, Kwame Nkrumah University of Science and Technology, Ghana

Erdoğdu, E. (2013). Insan kaynaklarl yönetiminde personel seçimi ve psikoteknik testlerin önemi, Degree of Master Thesis, Atılım University, Graduate School of Social Science, Ankara.

Geylan, R. (1992). Personel Yönetimi. Eskişehir: Met Publication.

Gusdorf, M. L. (2009). Recruitment and Selection: Hiring the Right Person. USA: Society for Human Resource Management Academic Initiatives.

Hall, A. (2012). The 7 C's: How to Find and Hire Great Employees. Accessed: 24.12.2014,http://www.forbes.com/sites/alanhall/2012/06/19/the7-cs-how-to-find-and-hire-great-employees/

Hanhan, U. (2006). Uluslararası denizcilikte donatan işletmelerinin personel seçim ölçütleri: İmir Bölgesi analizi, Degree of Master Thesis, Dokuz Eylül University, Graduate School of Social Science, Izmir. 
Harbili, R. (2009). İnsan kaynaklart yönetiminde personel seçim süreci ve elektronik sektöründe bir örnek olay çalışması. Degree of Master Thesis, Celal Bayar University, Graduate School of Social Science, Manisa.

Hinrich, J.U.S., Hollnagel, E., Baldauf, M. Hofmann S. \& Kataria, A. (2013). Maritime human factors and IMO policy. Maritime Policy \& Management. 40(3), 243-260.

INTERTANKO (International Association of Independent Tanker Owners). (2013). TOTS (Tanker Officer Training Standards). Accessed: 18.05.2013 http://www.marlins.co.uk/downloads/tots/tots_faq.pdf.

İbicioğlu, H. \& Ünal, Ö. F. (2014). Analitik hiyerarşi prosesi ile yetkinlik bazlı insan kaynakları yöneticisi seçimi. Atatürk Üniversitesi İktisadi ve İdari Bilimler Dergisi. 28(4), 55-78.

İstemi, J. (2006). Personel seçiminde analitik hiyerarşi metodunun kullanılmasl, Degree of Master Thesis, İstanbul Technical University, Graduate School of Science Engineering and Technology, İstanbul.

İTO (İstanbul Chamber of Commerce). (2004). The Profile of Maritime Transport Industry. Accessed: 11.03.2013, http://www.ito.org.tr/Dokuman/Sektor/1-26.pdf.

Karasar, N. (2005). Scientific Research Method. Ankara: Nobel Publication.

Karatepe, Ö. (2012). İnsan Kaynakları Yönetimi. Ankara: TOBB.

Kenan, K. (1996). Yöneticinin Kılavuzu: İnsan Seçme. İstanbul: Remzi Publicshing House.

Maloney, T. R. (2001). Employee Recruitment and Selection: How to Hire the Right People. USA: Cornell University.

Mondy, R.W., \& Noe, R.M., Premeaux, S.R. (2002). Human Resource Management. New Jersey: Prentice Hall. 
Mtsweni, J. (2008). The role of educators in the management of school discipline in the Nkangala Region of Mpumalanga, Degree of Master Thesis. University of South Africa.

Nas, S. (2006). Gemi operasyonlarının yönetiminde kaptanın bireysel karar verme süreci analizi ve bütünleşik bir model uygulamasl, Degree of $\mathrm{PhD}$ Thesis, Dokuz Eylül University, Graduate School of Social Science, Izmir.

Özdoğan, E. (2005). İşe alma ve yerleştirmede dış kaynak kullanımının çözümlemesi: Danışmanlık firmaları üzerine bir araştırma, Degree of Master Thesis, Dokuz Eylül University, Graduate School of Social Sciences, Izmir.

Özev, M. H. (2010). Petrol sermayesi ve uluslararast ilişkiler: 1973 sonrası körfez ülkeleri örneği. Degree of PhD Thesis, Marmara University, Institute Research of Middle East and Islamic Countries, İstanbul.

Rowbotham, M. (2014). Introduction to Marine Cargo Management. New York: CRC Press.

Sakar, C. (2013). Kimyasal Tankerlerde Operasyonel Etkinlik. İstanbul: Beta Press.

Sözen, U. (1973). Yönetici Değerlemesinde Personel Seçiminin Bir Faktör Olarak Kullanılması, Ankara: Ankara Economic and Commercial Sciences Academy Press.

Stewart, C.J. and Cash, W.B. (1985). Interviewing: Principles and Practices (4th edition). Dubuque, Iowa: W.C. Brown Publishers.

Theotokas I. and Progoulaki M. (2007). Cultural diversity, manning strategies and management practices in Greek shipping. Maritime Policy \& Management. 34(4), 383- 403. 